https://doi.org/10.15407/scin16.01.054

VOVK, M.I., HALIAN, Ye.B., and KUTSIAK, O.A. International Research and Training Center for Information Technologies and Systems of the NAS of Ukraine and Ministry of Education and Science of Ukraine 40, akad. Hlushkov Ave., Kyiv, 03187, Ukraine, +380 44526 2549, +380 44526 1570, vig@irtc.org.ua

\title{
COMPUTER SOFTWARE \& HARDWARE COMPLEX FOR PERSONAL ORAL SPEECH RESTORATION AFTER STROKE
}

Introduction. The speech disorders are one of stroke consequences, among which motor aphasia occupies a significant place.

Problem Statement. Synthesis of effective methods and means of oral speech restoration is an urgent scientific and practical task.

Purpose. To develop a computer appliance for oral speech restoration of mass application.

Materials and Methods. Structural and functional modeling, myostimulation, mathematical apparatus of predicate logic, $C \#$ and ActionScript 2.0 programming languages.

Results. The PROMOVA-2 software E hardware appliance for individual speech restoration has been developed. It uses the innovative technology of speech restoration based on movements training of the affected hand and fingers after stroke. The appliance consists of TRENAR ${ }^{\circledR}$ electronic devices for training motor functions of the affected hand by different methods and programs of myostimulation and ProMova 1.2 software module in the PC structure.

ProMova 1.2 contains the speech disorder diagnosis module that uses software for quantitative assessment of motor and sensory components of speech; the unit to help a doctor in the formation of individual plan for training of affected hand proceeding from the results of diagnosis; the patient's medical records database, and the knowledge base with information on the operation of TRENAR ${ }^{\circledR}$ devices and hand training techniques.

The supporting documents (guidance on the practical use of PROMOVA-2 and user manual of the ProMova 1.2 module) will facilitate the mass use of the appliance. The results of the clinical trial have shown a greater efficiency of the innovative speech restoration method implemented using the appliance as compared with the basic rehabilitation course.

Conclusions. The PROMOVA-2 hardware $\mathcal{E}$ software appliance for individual oral speech restoration performing several functions (diagnosis, speech restoration, and speech restoration knowledge transfer) may be recommended for mass use.

Keywords: stroke, oral speech, hand motor skills, restoration, computer appliance, electronic devices, program module, and myostimulation.

Citation: Vovk, M.I., Halian, Ye.B., and Kutsiak, O.A. Computer Software \& Hardware Complex for Personal Oral Speech Restoration after a Stroke. Sci. innov. 2020. V. 16, no. 1. P. 54-68. https://doi.org/10.15407/ scine16.01.054 
One of the stroke consequences is speech disorders, among which the most common is motor aphasia caused by damage of the cerebral cortex motor speech zone where the motor program of speech act is formed. The patient loses the ability to speak because of impaired motor commands. In similar way, disorders of motor functions after stroke are caused by impaired motor commands in the motor areas of the cerebral cortex whose neurons organize the motor act. Muscular movements of the speech apparatus are a type of voluntary movements.

The speech disorder significantly complicates and slows down the rehabilitation process, reduces the communicative capacity of patients, and leads to their social isolation. The synthesis of effective methods and technologies of speech restoration and the development of tools for their rapid and high-quality implementation are important research and applied tasks.

Previous studies have proposed a new method and developed an information technology for the restoration of verbal speech based on training of fine motor skills of the patient's affected arm after stroke [1]. The technology is implemented by means of PROMOVA software \& hardware appliance for speech restoration. It consists of TRE$N A R^{\circledast}$ electronic devices that give signals for purposeful training of fine motor skills of the affected arm using different myostimulation methods and programs, and a personal computer with ProMova 1.0 specialized software module as information component [2].

The PROMOVA application has resulted in a $32.5 \%$ improvement in the function of the speech motor component as compared with the basic rehabilitation rate $(p<0.02)$, which gives reasons for introducing innovative speech restoration technology into the mandatory rehabilitation package. The above indicators reflect the expert evaluation of the qualitative nature.

The mass use of the PROMOVA appliance is largely determined by the objective evaluation of positive dynamics of speech function deficiency as a result of rehabilitation activities, which is im- portant in the quantitative assessment of speech function deficiency by evidence-based criteria. Quantitative assessment is an important component of digital medicine, which helps the physician to estimate the effectiveness of the rehabilitation process and to formulate an individual rehabilitation plan based on an objective evaluation. A user-friendly computer system is another important component.

The purpose of the research is to prepare the PROMOVA software and hardware appliance for the restoration of oral speech after stroke for mass use, based on new methods and information technologies. The research includes the following works:

- to develop, to improve, and to implement the functional modules of new specialized software ProMova 1.2 of the PROMOVA-2 complex, which extends the functionality of the program module from the diagnosis of speech deficiency based on quantitative estimate of the deficiency to the development of an individual rehabilitation plan;

- to ensure ease of user's interaction with the computer appliance while using the new technology for speech restoration;

- to make clinical tests of the PROMOVA-2 computer appliance in the course of speech restoration treatment of stroke patients with movement disorders of hemiparesis type and speech disorders of motor or motor-sensory aphasia type;

- to develop supporting documentation that facilitates mass introduction of the PROMOVA-2 computer software \& hardware appliance for speech restoration.

\section{OBJECTIFICATION OF ASSESSMENT OF SPEECH RESTORATION TREATMENT RESULTS}

While evaluating the results of speech restoration, quantitative assessment by evidence-based criteria is an important factor. The main purpose of this research is to develop a method for quantitative evaluation of the degree of speech disorder after stroke based on the informative indicators 
of the condition of not only the motor, but also the sensory components of speech. This assessment makes it possible to take into account the degree of disorder of the speech sensory component while developing an individual plan for training of fine motor skills and to objectively evaluate the speech restoration results.

The developed method [3] provides for stageby-stage evaluation of the sensory (comprehension of spoken speech) and the motor (oral speech) components of speech based on patient's performance of certain test assignments. Each stage includes sections that reflect, on the one hand, the specifics of the disorder (expressive or impressive component of speech) and, on the other hand, its systematicity (disorders of different speech aspects) (Fig. 1) [4].

The assignments are based on well-known tests used in speech therapy, as well as tests to assess the severity and dynamics of stroke in neurology.

The degree of severity of speech disorders is determined separately for each component by the total points scored by the patient during the performance of assignments from different sections. The number of degrees of expression of the sensory and motor components is unified. The quantitative scale for assessing the depth of speech disorders distinguishes the four degrees of aphasia: slight, moderate, massive, and heavy. The absence of aphatic disorders is also recorded.

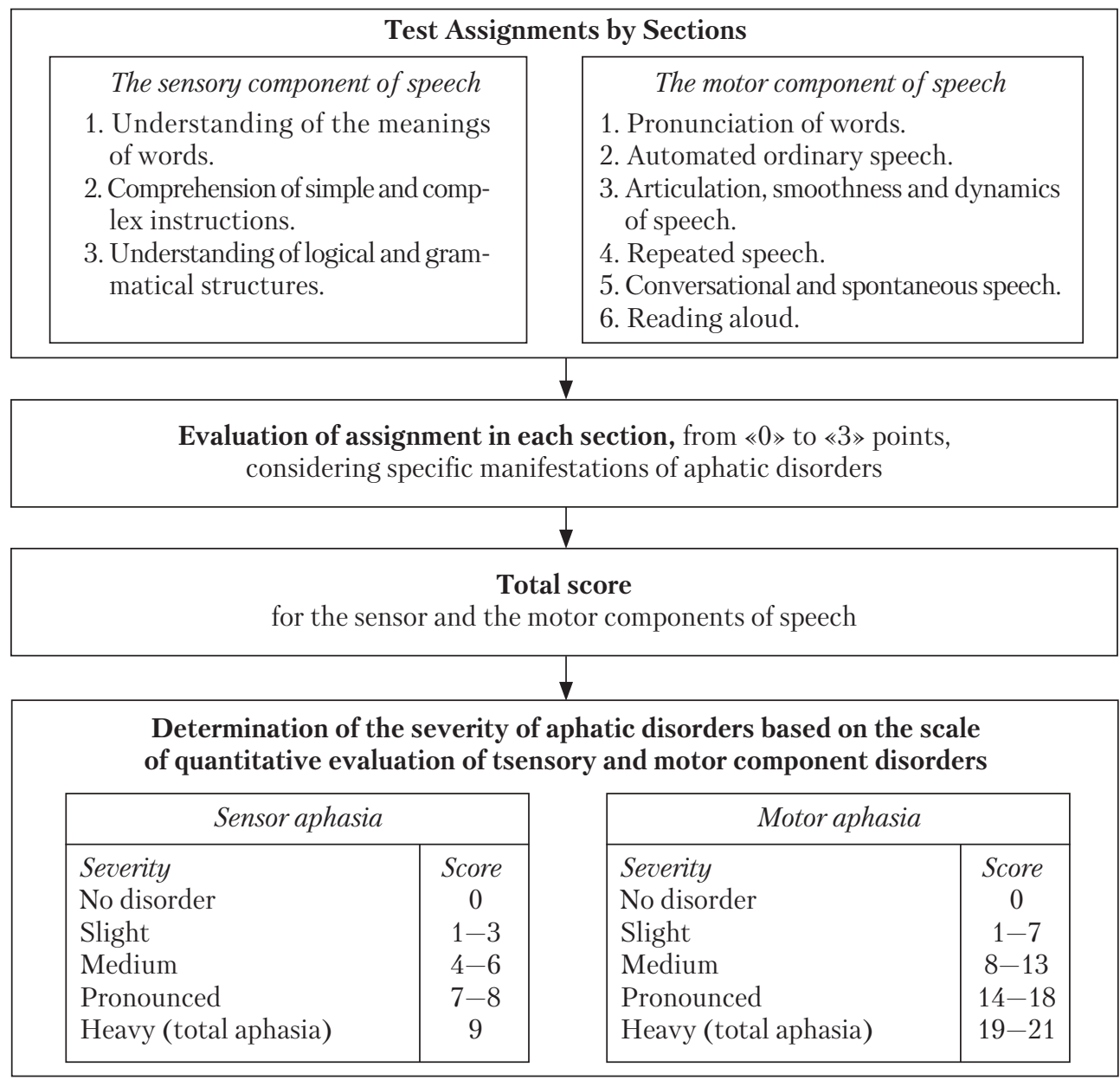

Fig. 1. Algorithm for quantitative express assessment of severity of speech deficiency in stroke patients with aphatic disorders 
It is advisable to conduct a test of the degree of speech disorder before evaluating, after five sessions, and after completion of the course, to evaluate the results of speech restoration therapy based on individual training of fine motor skills. The status of improvement of the speech motor component is assigned if there are changes in the pathological function of speech, based on which the doctor diagnoses a milder degree of pathology as a result of rehabilitation; the slight improvement is assigned if there is a change in the severity of the speech motor component disorder as compared with that diagnosed before the start of the course.

The proposed method of express evaluation of the severity of motor and sensory speech disorders in stroke patients with aphasia has several advantages:

- the test assignments are focused on detecting both the specifics of the defect (sensory or / and motor components of speech) and its systematicity (disorders of different aspects of speech);

- the main symptoms of aphatic disorders in the case of Broca's motor aphasia and their specific manifestations in each function, in particular: agramatism, anomia, difficulty of articulation, paraphasia, perseverations, disorders of comprehension and perception of spoken speech are taken into account while evaluating the functions of the motor and sensory components of speech;

- reduced time of the survey;

- simplicity and accessibility of the survey algorithm for non-pediatric specialists, first of all, for neurologists;

- no need for additional printed materials to perform the test assignments, since the method uses environmental objects;

- unification of the quantitative assessment of the severity of the motor and sensory speech disorders $(0,1,2,3)$ for each test assignment and the non-overlapping limits of the total quantitative assessment of the degree of disorders of the motor and sensory components of speech (slight, moderate, massive, heavy) reduce the expert error.

\section{PROMOVA 1.2 SPECIALIZED SOFTWARE MODULE FOR INFORMATION SUPPORT OF PHYSICIAN IN THE COURSE OF SPEECH RESTORATION IN STROKE PATIENTS AS COMPONENT OF PROMOVA-2 APPLIANCE}

Specialized ProMova 1.0 software module designed for the wide use of PROMOVA appliance needed to be improved. Its disadvantages included:

- the absence of module for diagnosis of speech disorders using the method of quantitative assessment of the degree of speech disorders, which complicates the determination of positive dynamics while treating speech function deficiency in patients with stroke;

- no adjustment of the recommended training plans by a separate function module; for this, physician needs to use other applications (text editors, such as Notepad that is part of Microsoft Windowes, Microsoft Word operating systems, etc.);

- the absence of a sub-module that describes the criteria and explains the algorithms for selecting the parameters of individual training plans for restoring patient's hand fine motor skills based on informative indicators of patient's condition and methodological recommendations for the use of the appliance in the functional module of knowledge transfer to physician.

The structural and functional model of the advanced specialized software module is shown in Fig. 2. The physician interacts directly with the graphical user interface in a dialog mode. This interface allows him/her to get access to information, to input values of informative indicators of patient's condition by the selected criteria for their further analysis, and to print out a recommended and adjusted individual rehabilitation plan, results of rehabilitation and other information. 


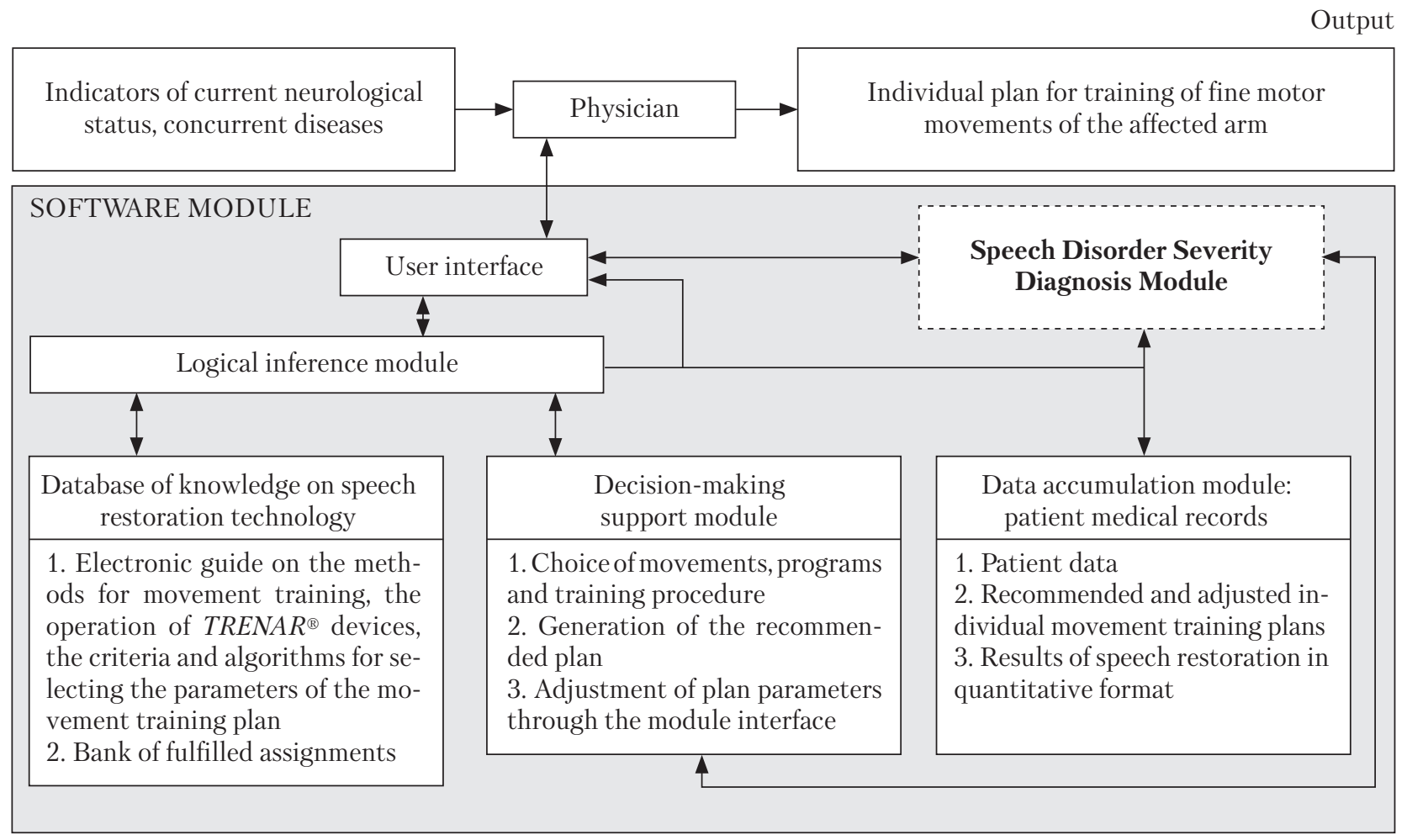

Fig. 2. Structural and functional model of ProMova 1.2 software module

For improving the graphical interface performance, as compared with ProMova 1.0, the new application provides the ability to input and to save test results for quantifying speech deficiency, to monitor their dynamics as a result of rehabilitation activities and to adjust the training plan parameters.

The module for diagnosis of the degree of speech disorder added to the structural and functional model of a specialized software module, in interaction with the data storage module implements the developed method for quantitative express evaluation of speech restoration results in stroke patients.

The data accumulation module is a database of patients' medical records. It enables the recording and storage of patient information: passport data, recommended and adjusted individual training plans, and treatment outcomes. It also provides the physician with tools for recording the course of treatment.
In addition to the previously developed electronic multimedia references on methods for training hand fine motor skills and the bank of solved assignments, there has been added the knowledge base module that contains a description of the criteria and algorithms for selecting the parameters of the training plan, a set of possible training plans, recommendations.

The decision support module implements analytical expressions of the method for identifying an individual set of control actions for speech restoration, as well as provides tools for generating and maintaining recommended and adjusted training plans.

The inference module is responsible for comparing the input data from the interface and the module of diagnosis of speech disorders with the information from the knowledge base module with the subsequent formation of decision on individual plan for training of hand fine motor skills for speech restoration in stroke patients with aphatic 
disorders. It enables solving many problems: the choice of exercises for training programs depending on the value of informative indicators of patient's condition, in particular, speech function; the generation of rehabilitation plan (the choice of number of procedures and their parameters); the adjustment of parameters of the rehabilitation course in progress; and the evaluation of treatment outcomes.

\section{The formation of individual map for the rehabilitation training of movements of hand and fingers}

Materials and methods: mathematical apparatus of predicate logic to develop and to syntactically present a set of criteria and decisive rules for the formation of a rehabilitation course map for training of hand fine motor skills; Unified Modeling Language (UML) to design a specialized program module architecture and to describe the functional interaction of its components. Software implementation/support: Microsoft Visual Studio 2013 and SroishMax 4.0 environments, C\# and Action-
Script 2.0 programming languages, Sony Vegas 6.0 software.

\section{Developing an individual map for rehabilitation course for training of hand and finger movements}

Combines determining the possibility of a rehabilitation course based on the analysis of contraindications specific to the proposed method for controlling fine motor movements; forming an individual set of controlling actions depending on patient's condition.

Together with the experts, the authors have distinguished many informative indicators of patient's condition based on which an individual set of controlling actions is chosen (Table 1) [5].

Each informative indicator $X_{n}$ has its own set of values $x_{n 1}, x_{n 2}, \ldots x_{n m}$, where $n$ is the ordinal number of the patient's current status indicator, $\mathrm{m}$ is the number of elements in the set of values. Respectively, $X_{n}\left\{x_{n m}\right\}$ is value $\mathrm{m}$ of indicator $n$.

To determine the possibility of a rehabilitation course, there have been developed criteria for the detection of specific contraindications (hyperto-

Table 1. Informative Indicators of the Patient's Condition

\begin{tabular}{|c|c|c|c|c|c|c|c|}
\hline Indicator of patient's condition & Designation & \multicolumn{6}{|c|}{ Value of indicator/its designation } \\
\hline Electrocardiosimulation & $X_{0}$ & \multirow{4}{*}{\multicolumn{6}{|c|}{$\begin{array}{l}\text { Present }- \text { yes } / x_{01} \\
\text { Absent }- \text { no } / x_{02} \\
\text { 1. Normal / } x_{11} \\
\text { 2. Emotional lability / } x_{12} \\
\text { 3. High-grade emotional lability / } x_{13} \\
\text { 4. Emotional depression } / x_{14} \\
\text { 5. Signs of depression / } x_{15} \\
\text { There are disorders that prevent the patient from understanding } \\
\text { and following simple instructions }- \text { Yes } / x_{21} \\
\text { No disorder or slight disorder }- \text { No } / x_{22} \\
\text { Assessment of the level based on L. McPeak and M. Weiss scale }\end{array}$}} \\
\hline Emotional and volitional sphere & $X_{1}$ & & & & & & \\
\hline Sensor component & $X_{2}$ & & & & & & \\
\hline \multirow[t]{2}{*}{ Muscular strength in injured limb } & \multirow[t]{2}{*}{$X_{3}$} & & & & & & \\
\hline & & $0 / x_{31}$ & $1 / x_{32}$ & $2 / x_{33}$ & $3 / x_{34}$ & $4 / x_{35}$ & $5 / x_{36}$ \\
\hline \multirow[t]{2}{*}{ Muscular tone in injured limb } & \multirow[t]{2}{*}{$X_{4}$} & \multicolumn{6}{|c|}{ Assessment of pathology severity based on Ashworth modified scale } \\
\hline & & $0 / x_{41}$ & $1 / x_{42}$ & $1+/ x_{43}$ & $2 / x_{44}$ & $3 / x_{45}$ & $4 / x_{46}$ \\
\hline $\begin{array}{l}\text { Concurrent diseases (diabetes, atrial } \\
\text { fibrillation (permanent form)) } \\
\text { Sensitivity to electrical stimulation }\end{array}$ & $X_{5}$ & \multicolumn{6}{|c|}{$\begin{array}{l}\text { Present }- \text { Yes } / x_{51} \\
\text { Absent }- \text { No } / x_{52} \\
\text { Increased }- \text { Yes } / x_{61} \\
\text { Normal or reduced }- \text { No } / x_{62}\end{array}$} \\
\hline
\end{tabular}


nia of the muscles of the patient's involved arm and the presence of an electrocardiostimulator in patient with cognitive disorders and severe or moderate hemiparesis):

$$
\begin{gathered}
\forall X_{0} \wedge \forall X_{1} \wedge \forall X_{2} \wedge \forall X_{3} \wedge\left(X_{3}\left\{x_{45}\right\} \vee X_{4}\left\{x_{46}\right\}\right) \\
\wedge \forall X_{5} \wedge \forall X_{6} \Rightarrow S\left\{s_{1}\right\} \\
X_{0}\left\{x_{01}\right\} \wedge \\
\wedge\left(\begin{array}{c}
\left(X_{1}\left\{x_{13}\right\} \vee X_{1}\left\{x_{14}\right\}\right) \vee X_{2}\left\{x_{21}\right\} \vee \\
\vee\left(X_{3}\left\{x_{31}\right\} \vee X_{3}\left\{x_{32}\right\} \vee X_{3}\left\{x_{33}\right\} \vee X_{3}\left\{x_{34}\right\}\right) \vee \\
\vee
\end{array}\right) \wedge\left(X_{4}\left\{x_{43}\right\} \vee X_{4}\left\{x_{44}\right\}\right) \\
\wedge \\
\wedge X_{5} \wedge \forall X_{6} \Rightarrow \mathrm{S}\left\{s_{2}\right\} .
\end{gathered}
$$

Based on the developed criteria the decisive rule for permitting a rehabilitation course is built:

$$
\overline{\mathrm{S}\left\{s_{1}\right\}} \wedge \overline{\mathrm{S}\left\{s_{2}\right\}} \Rightarrow C_{0} .
$$

The next stage of the method, the formation of an individual set of controlling actions (movements, control method and regulation), depending on patient's condition, is performed only if rule (3) is met. The criteria for determining the two options for training regimen of the rehabilitation course $A\left\{a_{1}\right\}$ and $A\left\{a_{2}\right\}$, with normal and reduced loads have been formed, together with experts:

$$
\begin{gathered}
\forall X_{0} \wedge\left(X_{1}\left\{x_{13}\right\} \vee X_{1}\left\{x_{12}\right\} \vee X_{1}\left\{x_{14}\right\} \vee X_{1}\left\{x_{15}\right\}\right) \Rightarrow \\
\wedge \forall X_{2} \wedge \forall X_{3} \wedge \forall X_{4} \wedge\left(X_{5}\left\{x_{52}\right\} \vee X_{6}\left\{x_{62}\right\}\right) \Rightarrow A\left\{a_{1}\right\} .(4) \\
\forall X_{0} \wedge\left(X _ { 1 } \{ x _ { 1 3 } \} \wedge \forall X _ { 2 } \wedge \forall X _ { 3 } \wedge \forall X _ { 4 } \wedge \left(X_{5}\left\{x_{51}\right\} \vee\right.\right. \\
\left.X_{6}\left\{x_{61}\right\}\right) \Rightarrow A\left\{a_{2}\right\} .
\end{gathered}
$$

It should be noted that a set of movements and methods for their training in the set of controlling actions shall be determined simultaneously, as they correlate with each other. The movement control program combination $B\left\{D\left\{d_{l}\right\}, F\left\{f_{k}\right\}\right\}$ consists of hand fine motor movement $D\{d\}$ and training program $F\left\{f_{k}\right\}$ offered by TRENAR-01 and/or TRENAR-02 devices. The total number of possible combinations, taking into account the ability to obtain movement under a given training program, is 17 .
The criteria for determining the individual set of movement - control program combinations are developed in several stages. Initially, the criteria are formed separately for the selection of each movement and training program. Based on them, the selection criteria for each of the 17 motion control program combinations are formulated. Inasmuch as the matching combinations show signs of conflict, the combinations with the same antecedents are combined to eliminate this conflict. As a result, 8 sets $R\left\{r_{j}\right\}$, containing two or three movement - control program combinations have been found. For selecting several sets $R\left\{r_{j}\right\}$ in one rehabilitation course and avoiding repeated output cycles while doing this, an algorithm for the sequence of analysis of informative indicators has been developed (Fig. 3) [5].

Based on the proposed criteria for determining the control procedure, the set of movement control program combinations, and the algorithm of sequence of analysis of informative indicators, the decisive rules for individual speech restoration map have been developed [5]. Proceeding from the definitions of logical functions: $R_{1} \wedge A\left\{a_{1}\right\}=$ $=K_{11}, R_{2} \wedge A\left\{a_{1}\right\}=K_{12}, R_{1} \wedge A\left\{a_{2}\right\}=K_{21}, R_{2} \wedge A\left\{a_{2}\right\}=$ $=K_{22}$, we have the following decisive rules set by the logical functions:

$$
\begin{gathered}
K_{11} \vee K_{21} \vee K_{12} \vee K_{22} \Rightarrow C_{1} \vee C_{2} \vee C_{3} \vee C_{4}, \\
\left(R_{3}+R_{7}+R_{8}\right)\left(K_{11}+K_{12}\right) \Rightarrow \\
\Rightarrow C_{5}+C_{6}+C_{7}+C_{8}+C_{9}+C_{10}, \\
\left(R_{3} R_{4}+R_{3} R_{5}+R_{3} R_{6}\right)\left(K_{12} \vee K_{22}\right) \Rightarrow \\
\Rightarrow C_{11} \vee C_{12} \vee C_{13} \vee C_{14} \vee C_{15} \vee C_{16} .
\end{gathered}
$$

In total, analytical expressions (6)-(8) define 16 possible options of rehabilitation course map.

\section{Structure and functional characteristics of the information component}

Using an individual approach to the rehabilitation course in the developed technology of speech restoration complicates the choice of individual set of controlling actions (movement, training program and rules). 


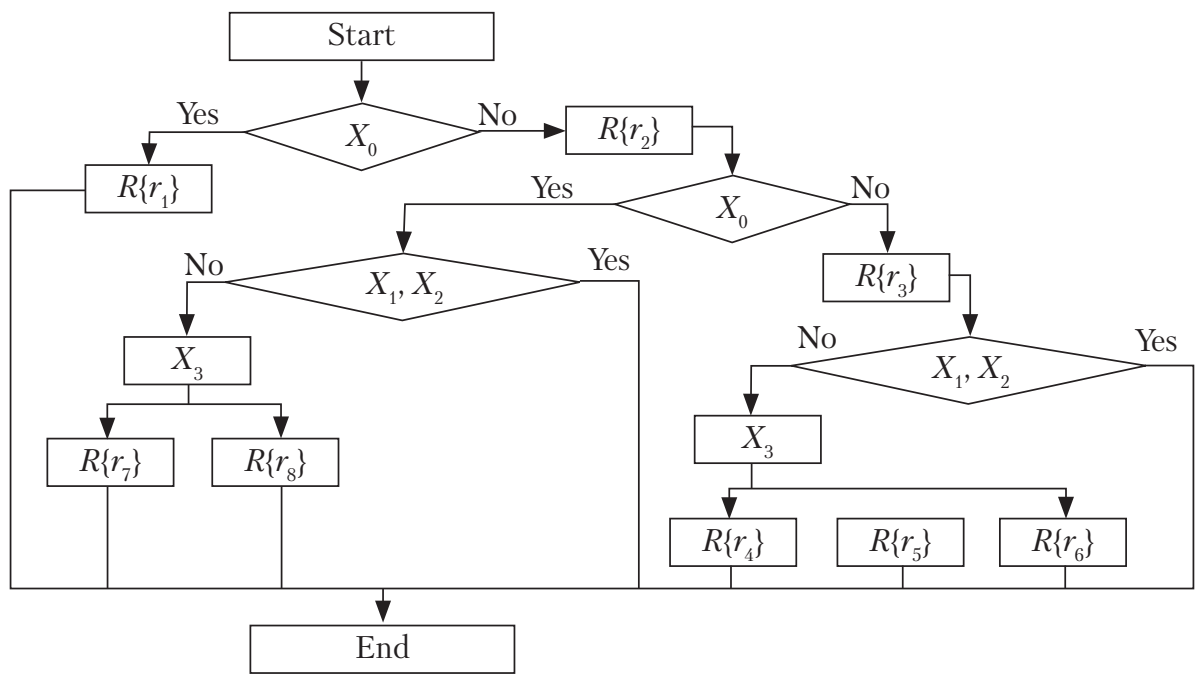

Fig. 3. Algorithm for sequence of analysis of informative indicators of patient's condition

To solve the problem of multicriteria selection of an individual set of controlling actions (in the case of training of hand fine motor skills) an information component has been synthesized in the structure of the outer contour for control of hand and finger movements. It is implemented as a specialized software module in the structure of personal computer. The information component is a reduced expert direct output system of productive type.

The analysis of structural and functional model of the information component (Fig. 2), in terms of scenarios of its use (functional characteristics), makes it possible to distinguish the modules for designing the diagnosis of speech disorders; the support of decision making on the formation of plans for rehabilitation courses; the transfer of knowledge of the technology for speech restoration based on training movements of hand and fingers; and the base of patient medical records. The modules are designed as standalone units with complete functionality and then are combined with each other through a graphical interface.

The module for diagnosis of speech disorders in the case of aphatic disorders. Since the method of express quantitative assessment of the severity of speech disorders has two stages of eva- luation separately for the sensor and for the motor component of speech, and each of them contains the same actions (performing test assignments and assessing the performance based on a four-point scale), the algorithm for the diagnosis of speech disorders (shown as chart in a UML notation) has a two-stage structure with a built-in loop (Fig. 4). First, a list of assignments for testing the sensor component, which contains three sections, is composed. The assignment data are placed in the knowledge base of the information component. Together with the list, a four-point scale for assessing the patient's performance with a description of the specific manifestations of speech function disorders is formed for each section.

The next step is the sequential display of assignments on the monitor by sections using a graphical interface for their subsequent performance by the patient. The cycle of test assignment display by sections on the monitor using a graphical interface is repeated three times. Each cycle, the doctor inputs the data of evaluation of the test assignment fulfillment and saves them. After completion of the cycle, the total score of the evaluation of the speech sensor component disorder is calculated and displayed to the user via GUI, with the data retained for further use. 


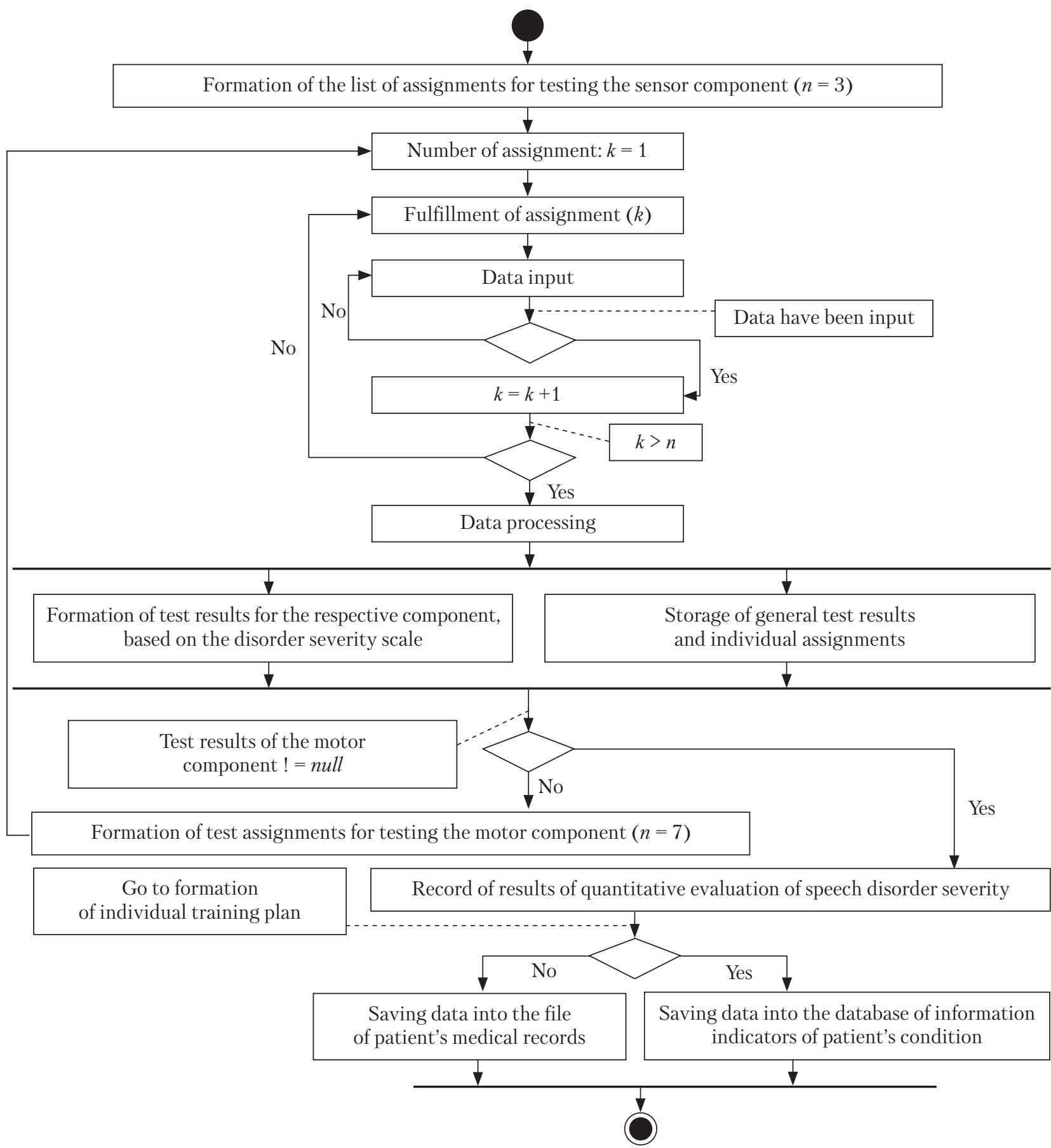

Fig. 4. Flowchart of Speech Disorder Diagnosis scenario

Later, the algorithm develops towards the second stage, where the same steps are performed to evaluate the motor component, but the cycle of test display on the monitor using the GUI is re- peated seven times. Upon completion of the test, the user is asked to save the results to a text file that is created in the patient's medical record or to submit them to the decision support module. 


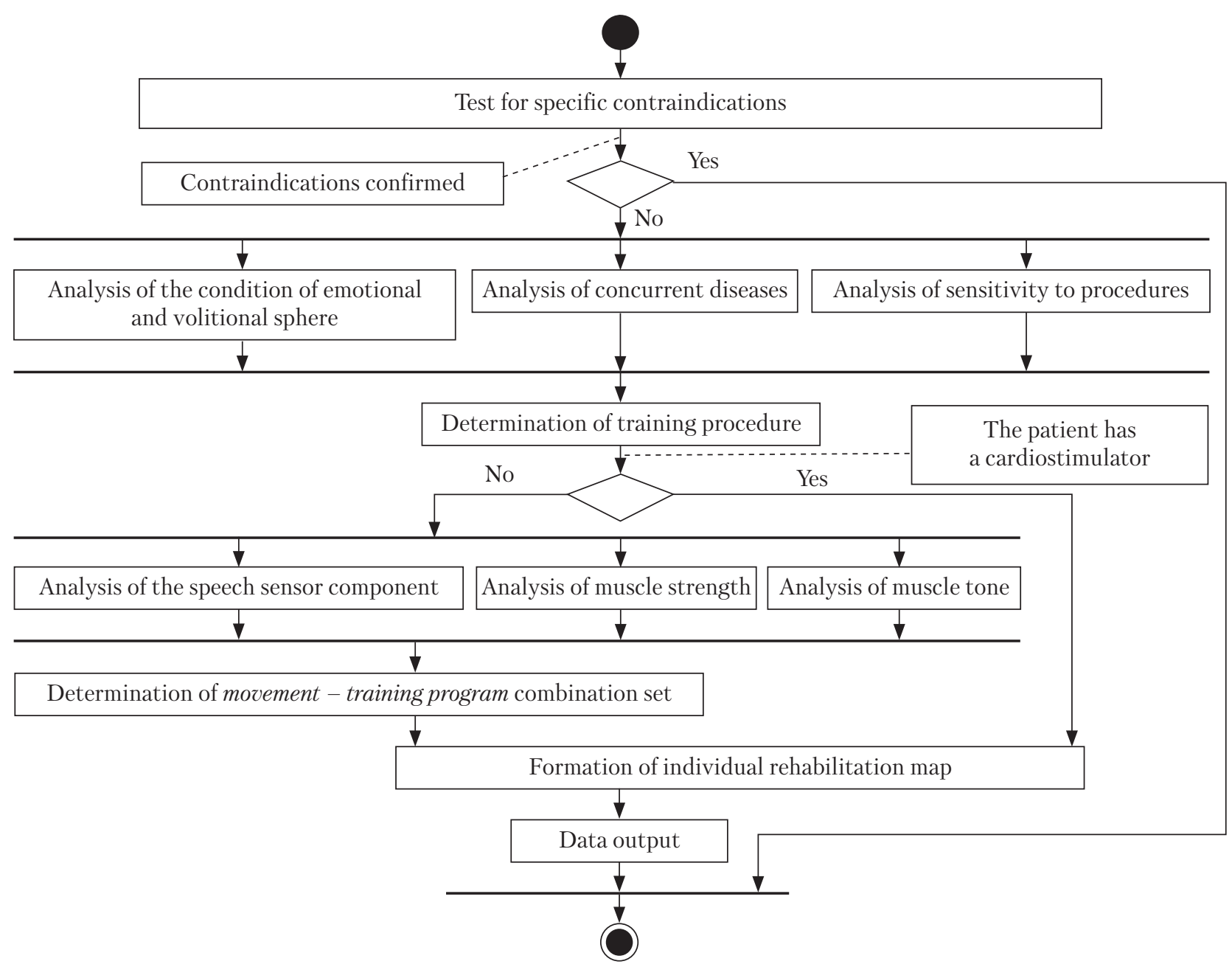

Fig. 5. Flowchart of the Formation of an Individual Set of Controlling Actions scenario

Creating a separate file for speech deficiency test results enables testing at the beginning, in the middle, and at the end of rehabilitation course, which ensures a quantitative evaluation of the treatment outcomes.

The help module provides assistance to physician in developing an individual plan for training of fine motor skills, together with the logical inference and knowledge base modules, gives recommendations for the formation of individual set of controlling actions (Fig. 5).

The activity chart has several stages: test for contraindications, determination of the training procedure, formation of an individual set of hand fine motor movement - training program combinations. When determining a set of combinations, the data are analyzed according to the algorithm of sequence of analysis of informative indicators: first, based on the criterion "presence of electrocardiostimulator", and then, if necessary, using all other criteria (Fig. 5).

The module for transfer of knowledge on speech restoration technology based on training of hand and fingers. The core of the module is an electronic multimedia directory, an organized database of digital information objects (in text, graphics, video, and audio formats) that carry information about methods and means of 


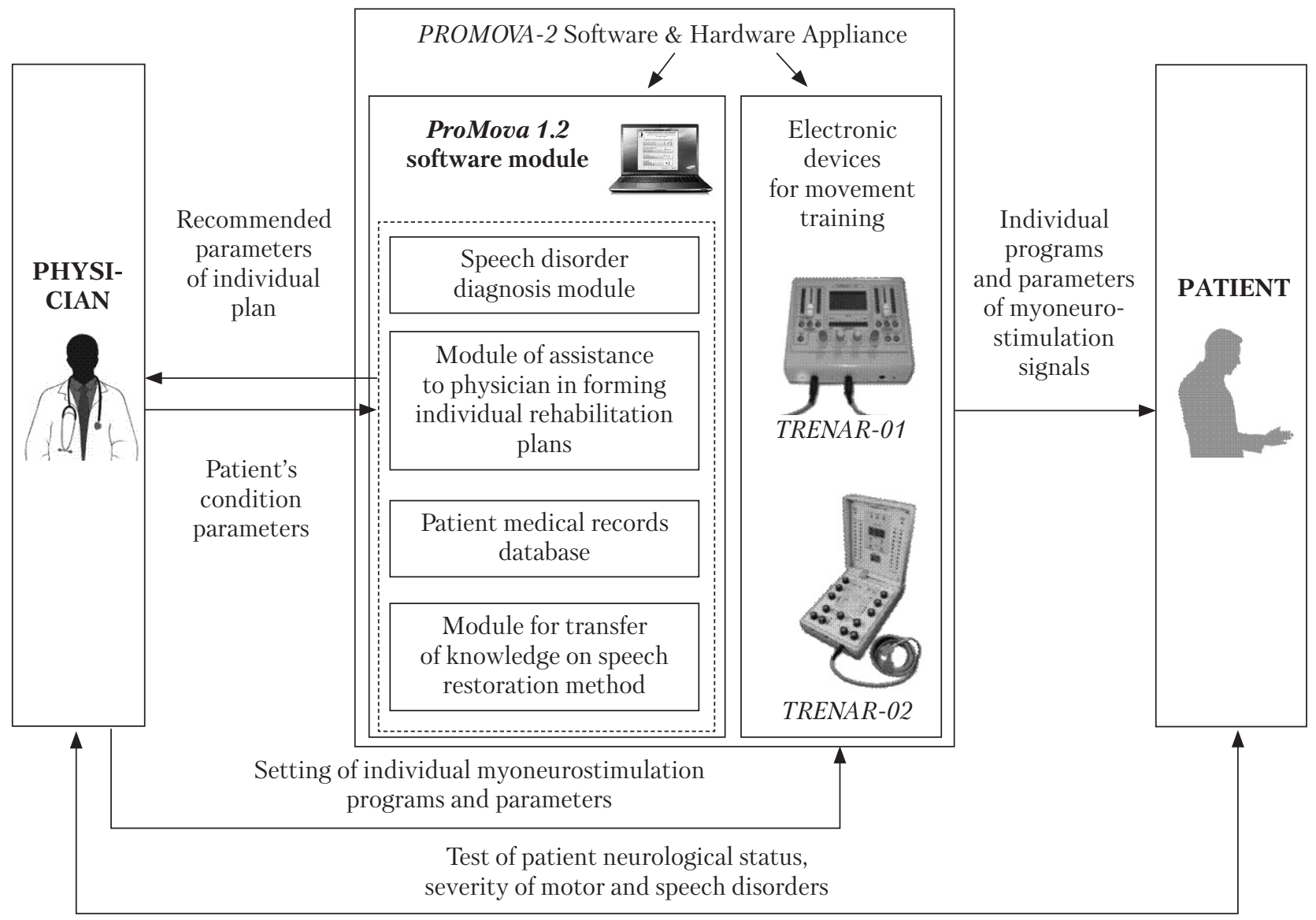

Fig. 6. Structural and functional model of interaction between physician, PROMOVA-2 complex, and patient

speech restoration technology. It also includes a set of software tools that implement the functions of access to the database, data processing and storage. The directory contains two different sections: the technical and the medical ones. The technical section performs the function of familiarizing the user of the program module with the principles of operation of TRENAR ${ }^{\circledR}$ devices. It provides information about the purpose, technical and functional characteristics of the devices, the list of components, as well as algorithms for preparing the devices for operation using different methods and programs, depending on reaction or events that may take place during the doctor's interaction with the controls.

The medical section is designed to provide information on the electrode placement techniques for the formation of various fine motor movements. It contains a graphical and a verbal representation of the electrode topology; a description of the muscles involved in the movement formation, their function and innervation; video demonstration of movement training in real clinical conditions with audio comments.

The specialized ProMova 1.2 software module is implemented in object-oriented C\# language, using additional software for the synthesis of multimedia technologies SroishMax 4.0 and SonyVegas 6.0. This module, in the PC architecture, together with the TRENAR ${ }^{\circledR}$ devices, forms the PROMOVA-2 computer software system.

The ProMova 1.2 software module contains tools for access to the developed methodological recommendations for the use of the PROMOVA-2 
appliance, which describe the criteria for selecting the parameters of an individual map of training, the algorithms of the appliance operation, and the methods of training hand and finger movements, depending on different combinations of informative indicators of the current status, based on the selected criteria. This improves the physician's understanding of the practicalities of the application of speech restoration technology using the PROMOVA-2 appliance. Also, the module interface contains the user manual that allows the doctor to master the software independently, without any support of a specialist.

The structural and functional model of the PROMOVA-2 software $\mathcal{E}$ hardware appliance for speech restoration. The PROMOVA-2 software \& hardware appliance for individual training of fine motor skills for speech restoration consists of TRENAR ${ }^{\circledR}$ electronic devices that give signals controlling the fine motor movements of affected hand, by different methods and programs, and a personal computer on which the specialized information and consulting module ProMova 1.2 is implemented.

The structural and functional model of interaction, transformation, and sequencing of information exchanged between the user (doctor), the patient, and the PROMOVA-2 appliance is presented in Fig. 6.

In the model under consideration, the doctor is an active link in the system and provides a single algorithm for the operation of the PROMOVA-2 appliance. He/she is the one who determines the degree of disorder of the motor and speech functions before / in the process / after the rehabilitation course; interacts with the appliance during the formation / adjustment of the map of the rehabilitation course, the establishment of individual methods, programs, and parameters of myoneurostimulation in separate procedures of the course.

Thus, the PROMOVA-2 computer software system ensures:

- the formation, correction and printout of an individual map of fine motor skills training for speech restoration;
- the training of hand and finger movements according to individual myoneurostimulation methods, programs, and parameters;

- information support of hand fine motor movement training for speech restoration.

The new functional module for diagnosis of speech disorders, the improved module for the formation of individual plan of trainings of movements and the knowledge transfer module, as well as the graphical interface of the ProMova 1.2 module have made it possible:

- to expand the target audience of the users, as it can be used for quantitative express evaluation of the dynamics of speech deficiency treatment in the case of aphatic disorders, both by neurologists and speech therapists;

- to expand the functionality of the appliance, to reduce the complexity and specificity of the doctor's interaction with the technical components of the systems due to the friendly interface and additional features described abov.

\section{CLINICAL TESTS OF THE PROMOVA-2 SOFTWARWE \& HARDWARE APPLIANCE}

The developed appliance has been tested in two stages. At the first stage, the functional capabilities of specialized software module ProMova 1.2 have been tested in terms of its convenience and usability for neurologists, specialists in rehabilitation, physiotherapy, and others on the basis of the Neurological Department No.1 of Kyiv City Clinical Hospital No. 3 and the Department for Rehabilitation Treatment of the Center for Innovative Medical Technologies of the NAS of Ukraine. The test results have confirmed the usability of the module. For the purpose of mass implementation and friendly use of the appliance by therapists, the methodical recommendations on its application and the ProMova 1.2 user manual have been developed and added to the knowledge base.

At the second stage, clinical tests of the $P R O$ MOVA-2 appliance for the rehabilitation treatment of speech in patients after stroke have been done on the basis of the aforementioned depart- 
Share of patients with

improvements, \%

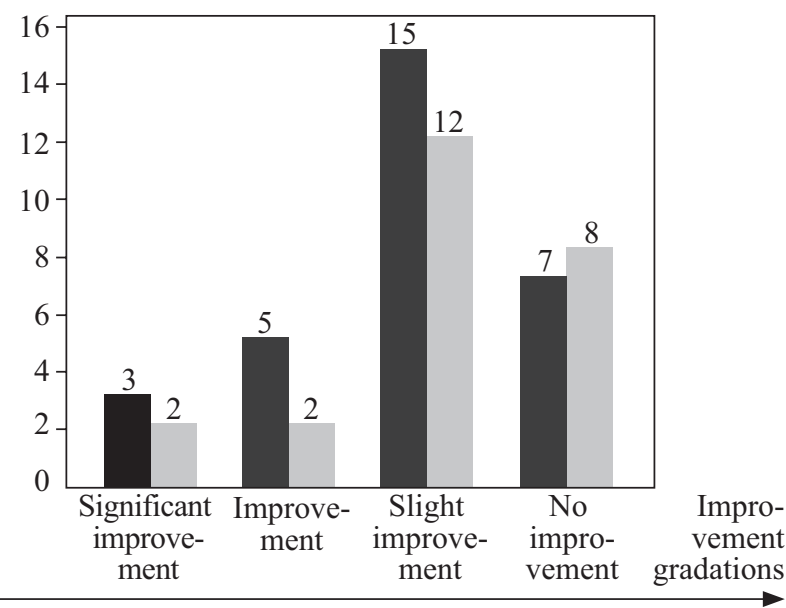

- Basic rehabilitation course +

+ training of hand fine motor movements

Basic rehabilitation course

Fig. 7. PROMOVA-2 clinical test results

ment of Kyiv City Clinical Hospital No. 3. Fifty four patients ( 28 men and 26 women) have been involved in the tests. The criteria for inclusion of patients in the study are: disorders of motor functions of right-sided hemiparesis type in the neurological status, speech function disorders of motor or motor and sensor aphasia of different severity caused by acute cerebral misperfusion.

All participants of the study have passed a basic comprehensive course of rehabilitation of motor and speech functions: medication therapy, therapeutic physical training, training with speech therapist. In addition, 30 participants have trained fine motor movements every weekday, according to an individual training map formed with the help of the ProMova 1.2 module [6]. Speech deficiency was diagnosed at the beginning and at the end of treatment. The results of the rehabilitation treatment are shown in Fig. 7.

The status of improvement of the speech motor component is assigned if there are changes in the pathological function of speech, based on which the doctor diagnoses a milder degree of pathology as a result of rehabilitation; the slight improvement is assigned if there is a change in the se- verity of the speech motor component disorder as compared with that diagnosed before the start of the course. The status of significant improvement of the speech motor component is assigned if there is an improvement in the degree of pathology, for example, from pronounced to slight motor aphasia.

The results of the clinical tests have confirmed the effectiveness of speech restoration technology implemented with the PROMOVA-2 computer software appliance in comparison with the basic rehabilitation course.

Based on the test results, the certificate on implementation of PROMOVA-2 Computer Software and Hardware Appliance in practical use at the Neurological Department No.1 of Kyiv City Clinical Hospital No.3 has been issued.

\section{CONCLUSIONS}

PROMOVA-2, a competitive hardware \& software appliance for individual speech restoration after stroke, has been developed for implementing a patented method of speech restoration based on purposeful training of the patient's hand and finger movements of the patient's affected arm and increasing the effectiveness of speech function restoration. The appliance consists of the TRE$N A R^{\circledR}$ electronic devices for training hand motor skills by different methods and programs of myostimulation and the ProMova 1.2 specialized software module installed in the PC structure to assist the doctor in the formation of an individual speech restoration plan. The parameters of the individual plan - a set of movements for training, program and procedure of training - are determined taking into account the current neurological status of the patient, the functional state of his/her motor and speech functions, the concurrent diseases and the contraindications.

The PROMOVA-2 computer appliance is ready for mass use. For this purpose, the improved ProMova 1.2 software module has been designed. As compared with the ProMova 1.0 software module, the ProMova 1.2 contains a module for diagnosis of the severity of speech disorders, which 
implements, by means of software, the method for express quantitative assessment of the severity of speech disorders. The functional module of the assistance in the formation of an individual training plan for hand fine motor movements has been improved in such a way as to enable adjusting the recommended individual plan at different stages of rehabilitation, taking into account the quantitative assessment of the state of the speech sensor component. The patient medical records database has been improved, with information on the severity of speech disorders, revised individual rehabilitation plans (if any), along with recommended plans added. The medical records database also contains information on the dynamics of speech function restoration, which takes into account quantitative assessment of both motor and sensor components with even slight changes. In addition to the multimedia instructions for operating the TRENAR ${ }^{\circledast}$ devices and the multimedia guide on the methods for training fine motor movements, the PROMova 1.2 knowledge transfer module has been supplemented with the methodical recommendations for the use of the PROMOVA-2 computer hard- ware \& software appliance. and the ProMova 1.2 software user's guide. These functions make it possible to expand the target audience of users and to simplify the use the PROMOVA-2 appliance. The supporting documents (the ProMova 1.2 user manual and the guidelines for the PROMO$V A-2$ practical use) will help to expand the use of innovative speech restoration technology for treating patients with stroke.

The PROMOVA-2 clinical tests have confirmed the convenience of its use. The clinical tests at the Neurological Department No. 1 of Kyiv City Clinical Hospital No. 3 have shown an improvement in the speech motor component in patients with motor disorder (right-sided hemiparesis) and speech function disorder of motor or motor and sensor aphasia (the certificate of implementation dated 18.12.2018).

The PROMOVA-2 Speech Restoration Computer Hardware \& Software Appliance that implements several original functions (diagnossis, rehabilitation, performance evaluation, and restoration technology knowledge) can be recommended for mass use.

\section{REFERENCES}

1. Patent of Ukraine № 111388. Vovk M. I., Halian Ye. B., Pidopryhora O. M. A method of treating speech disorders [in Ukrainian].

2. Galyan, E. B. (2014). Specialized Software Module of the Technology to Restore Speech; Architecture and Functional Integration of its Components. Control Systems and Computers, 6, 52-58 [in Russian].

3. Vovk, M. I., Peleshok, S. R., Galyan, E. B., Ovcharenko, M. A. (2016, February). Method for the motor and sensory speech disorders assessing. Collection of articles of the scientific information center "Knowledge" based on the materials of the XI international correspondence scientific-practical conference: "The development of science in the XXI century", part 3 (15 Feb 2016, Kharkiv), Dnipropetrovsk, 64-70 [in Russian].

4. Vovk, M. I., Halian, Ye. B., Kutsiak, O. A., Lauta, A. D. (2018). Formation of Individual Complex of Control Actions for Motor and Speech Rehabilitation after a Stroke. Kibernetika i vyčislitelnaâ tehnika, 3(193), 43-63 [in Ukrainian].

5. Vovk, M. I., Galyan, E. B. (2016). Organization of Intelligent Hand Movements Control to Restore Speech. Kibernetika $i$ vyčislitelnaâ tehnika, 184, 25-43 [in Russian].

6. Certificate of registration the copyright "Computer program of methods of fine motor function movements training for restoration of verbal speech in patients after stroke” / M. I. Vovk, Ye. B. Halian (Ukraine); No. 82086; published dated 9.10.2018 [in Ukrainian].

Received 23.04.19

Revised 07.06.19

Accepted 24.06.19 
M.І. Вовк, С.Б. Галян, О.А. Куияк

Міжнародний науково-навчальний центр інформаційних технологій та систем НАН та МОН України, просп. акад. Глушкова, 40, Київ, 03187, Україна, +380 $445262549,+38044526$ 1570, vig@irtc.org.ua

КОМП’ЮТЕРНИЙ ПРОГРАМНО-АПАРАТНИЙ

КОМПЛЕКС ПЕРСОНАЛЬНОГО ВІДНОВЛЕННЯ УСНОГО МОВЛЕННЯ ПІСЛЯ ІНСУЛЬТУ

Вступ. Одним з наслідків інсульту є порушення мовленнєвих функцій, серед яких моторна афазія займає значне місце.

Проблематика. Синтез ефективних методів і засобів відновлення усного мовлення - актуальне науково-прикладне завдання.

Мета. Розробка комп’ютерного комплексу відновлення усного мовлення для масового використання.

Матеріали й методи. Використано структурно-функційне моделювання, міостимуляція, математичний апарат логіки предикатів, мови програмування C\#, ActionScript 2.0.

Результати. Розроблено комп'ютерний програмно-апаратний комплекс персонального відновлення усного мовлення «ПРОМОВА-2», який реалізує інноваційну технологію відновлення мовлення на базі тренувань рухів кисті й пальців ураженої руки після інсульту. До складу комплексу входять електронні апарати ТРЕНАР® для тренування моторики кисті за різними методами й програмами міостимуляції та спеціалізований програмний модуль ProMova 1.2 у структурі ПК.

Модуль ProMova 1.2 містить: блок діагностики мовленнєвих порушень, який програмно реалізує методику кількісного оцінювання порушень моторного і сенсорного компонентів мовлення; блок допомоги лікарю у формуванні персонального плану тренувань кисті за результатами діагностики; базу медичних карт пацієнта; базу знань для ознайомлення з роботою апаратів ТРЕНАР® і методиками тренування кисті.

Супроводжувальна документація (методичні рекомендації з практичного використання комплексу «ПРОМОBA-2», посібник користувача модуля РroMova 1.2) сприятимуть масовому використанню комплексу. Результати клінічної апробації підтвердили більшу ефективність застосування інноваційної технології відновлення мовлення, яку реалізує комплекс, порівняно з базовим курсом реабілітації.

Висновки. Комп'ютерний програмно-апаратний комплекс персонального відновлення усного мовлення «ПРОMOBA-2», який реалізує гаму оригінальних функцій (діагностика, реабілітація, надання знань з технології реабілітації можна рекомендувати для масового використання.

Ключові слова: інсульт, усне мовлення, моторика кисті, реабілітація, комп'ютерний комплекс, електронні апарати, програмний модуль, міостимуляція. 